\title{
Adaptation Mechanisms in Agriculture for Climate Change in Nepal
}

\author{
Mina Nath Paudel
}

\begin{abstract}
In Nepal, impacts of climate change can be observed in varying levels of climate that are prevalent in diversified topography and vegetation. Broadly speaking, there are impacts of climate change in the Terai lowlands, the mid-hill valleys and mountains, and in the high Himalayas. Nepal is a unique climatic laboratory for studying the impacts of climate change.

Sixty-five percent of the Nepalese people engage in agriculture and more than $32 \%$ of Gross Domestic Product (GDP) comes from it. There are evidences of climate change in frequently changing monsoonal patterns resulting in droughts, floods, landslides, and other unexpected results that impair subsistence agriculture systems in the country. As a result, there is chronic food shortage in remote hills, and in the mountains, and the Terai, the grain bowl of Nepal, has been hit by food shortage. To date, around 3.9 million people have suffered from hunger and poverty. There are reports that major food crops of rice, maize, and wheat production have declined due to changes in monsoon patterns, insurgence of new pests, and decline in soil productivity. Efforts have been initiated to adopt drought and pest tolerant varieties, changes in planting time, and method of plantings as strategies for adaptation to climate change in agriculture. This paper attempts to highlight adaptation as a strategy to address issues of climate changes from the perspective of Nepalese agriculture.
\end{abstract}

Key words: Agriculture, climate change, adaptation, mitigation, Nepal

\section{Background}

The most general definition of 'climate change' is 1 a change in the statistical properties of the climate system when considered over long periods of time, regardless of cause (US EPA nd; Theodore 2001). Accordingly, fluctuations over periods shorter than a few decades, such as E1 Niño, do not represent climate change. The term is sometimes used to refer specifically to climate change caused by human activities, as opposed to changes in climate that may have resulted as part of Earth's natural processes (UNFCCC 1992).

Climate change is related to changes in the concentration of the greenhouse gases (water vapor, $\mathrm{CO}_{2}, \mathrm{CH}_{4}, \mathrm{~N}_{2} \mathrm{O}$, and CFCs), which trap infrared radiation from the earth's surface and thus cause the 'greenhouse effect'. This effect is a natural phenomenon, which helps maintain a stable temperature and climate on the earth. Anthropogenic activities, such as fossil fuel combustion, deforestation, and some industrial processes have led to an increase in greenhouse gases concentration. Consequently, more infrared radiation has been captured in the atmosphere, which causes changes in the air temperature, precipitation patterns, sea-level rise, and melting of glaciers (Central European University 1999). Sinha, Rao and Swaminathan (1988) state that the climate changes envisaged to the 21st century are mostly attributed to the increasing concentration of $\mathrm{CO}_{2}$ and other greenhouse gases. Rosenberg (1987) made an analysis of gas exchange and concluded that climate change, at least as far as $\mathrm{CO}_{2}$ concentration effects are concerned, may prove advantageous. However, Gifford (1987) made a more cautious assessment of $\mathrm{CO}_{2}$ effects by including temperature change as an additional component.

Similarly, the term 'adaptation' with respect to climate change has been used in myriads of forms and occasions. "Adaptation to climate change refers to adjustment in natural or human systems in response to actual or expected climatic stimuli or their effects, which moderates harm or exploits beneficial opportunities. Various types of adaptation can be distinguished, including anticipatory and reactive adaptation, private and public adaptation, and autonomous and planned adaptation" (IPCC 2001). Adaptation in other words is the process or outcome of a process that leads to a reduction in harm or risk of harm, or realization of benefits associated with climate variability and climate change (Harman, Gawith and Colley 2005).

The first key words in the definition that express adaptation as 'adjustment', 'practical steps', 'process' and 'outcome' can be interpreted differently by various stakeholders. 'Adjustment' seems to imply a process that leads toward some standard or goal (Ellina and Tirpak 2006). The Asia and Pacific region, because of its geographical and social diversity, will be affected by climate change in a variety of ways, including impacts on water resources, terrestrial and marine ecosystems, agriculture, coastal zones, infrastructure, and industries (IPCC 2001). Temperature increase and shifts in rainfall are likely to induce significant reductions in agricultural productivity, in spite of the fertilizing effect of increased atmospheric concentrations of $\mathrm{CO}_{2}$. This productivity decline will be exacerbated by soil degradation (Faisal and Parveen 2004). Flooding can also have a significant impact on rice crop production (IPCC 2001). Climate change will impose more stresses on the ecosystems of the boreal forests, mountains and highlands of Asia (Hay and Mimura 2006). Glacial melt in the Himalayas will also be accelerated by global warming. It is already appearing to causes serious problems due to the formation of glacier lakes and the risk of downstream flooding. Hay and Mimura (2006) also foresaw that low-lying deltas and small islands will be greatly affected by climate change and sea-level rise, which causes large-scale inundation along the vast Asian and Pacific coastline, erosion of sandy beaches, and adverse impacts on mangroves and coral reefs. 


\section{Climate Change and Nepal}

The end result of climate change is observed in agriculture and food security in general and poor and highly vulnerable populace in particular. Impact of climate change in Nepal could be observed in varying level of climates that are prevalent in diversified topography and vegetation present in Nepal (Paudel 2010). Broadly, there are impacts of climate changes in Nepal on; Terai (almost tropical region), mid-hills and valley (subtropical region), and mountains and the Himalaya (temperate and tundra regions). Nepal is a unique place representing in the form of world climatic laboratory to study impact of climate change. It was reported that there was no snow in the Kapi Himal of mid western region at 15,000 feet and pioneer mountaineer Mr. Apa Sherpa, the Goodwill Ambassador to Climate Change (Sherpa 2010) observed drastic changes in the climate of the Himalayas regions and speaks "the changes in weather patterns are drastic. It didn't snow at all during December, January and February, when it should snow heavily, and it finally snowed massively in May, when usually it's dry." Mr. Apa scaled the Mount Everest 19 times up to June 2009. He experienced while climbing Everest in June 2009 that there was no snow on Everest trail and he waited snow fall for days at the base camps to scale Mt. Everest because without snow, scaling the mountain is virtually impossible. He broke his own record and scaled Everest for the 20th time on 23 May 2010 and noticed that there was stream flowing on top of Everest by melting ice. Again Apa scaled Mount Everest for the 21st time on 11 May 2011, thus breaking his own record again (Shrestha 2009). What could be the more astounding impact of climate changes in the Himalayan region than this? A country like Nepal could not explain more than this as the impact of climate changes in the Himalayan region - the experience of Apa!

Aside from above consequences, Malla (2008) cited some of the impacts of climate change in Nepal. These include untimely start of monsoonal rainfall that resulted rain deficit in the eastern Terai lowlands in 2005/2006, reducing crop production by $12.5 \%$ nationwide. Also, about $10 \%$ of agricultural land was left fallow due to rain deficit on the one hand, while on the other hand the midwestern Terai faced heavy rain with floods, which reduced crop production by 30\% (Regmi 2007). As a result early maturity of the crops was observed, due to increase in temperature. Adverse effect of climate change could lead to the extinction of some indigenous crop varieties such as many aromatic rice varieties including Basmati Rice, some local wheat, maize, and other agricultural crops as well. It was also observed that a severe winter cold wave in Nepal in 1998 had negative impacts on agricultural productivity and showed a high percentage of yield reduction for potato (27.8\%), mustard (36.5\%), mustard seed (11.2\%), leaf mustard (30\%), lentil (37.6\%), and chickpea (38\%) (NARC $1987 / 88$ to $1997 / 98)$.

\section{Adoption and Mitigation Strategy of Climate Change}

The economies of developing countries depend heavily on climate-sensitive sectors such as agriculture, forestry, fisheries, water supply, and other natural resources. Climate sensitive sectors are generally affected by limited human capacity and limited access to technology and capital to invest in risk reduction. Thus, it is imperative that climate change adaptation is not separated from other priorities but is integrated into development planning, programs, and projects (World Bank 2008). Recently, unsustainable development practices for bioenergy production have been recognized as an additional threat and may have an impact on the goal of achieving food security. FAO (2008) underlined the need to think of food, energy and climate as one interconnected issue. Thus, to save the world from impending climate catastrophe through mitigation viz; direct reduction of greenhouse gases and their offsets and adaptation viz; support towards adapting to the effects of climate change, are available options to be implemented in the immediate future.

Of the several options, Nepal can select adaptation options based on hazard specificity and location specific preferences. FAO (2009) has provided practices to cope with climate change hazards, such as rain water harvesting and soil moisture conservation, slope stabilization and management, management of high/low temperature stress, crop diversification, community based seed production of staple crops, resource conservation, and cultivation of stress tolerant crop varieties.

In Nepal, more than $90 \%$ of the population is dependent upon the land for fulfillment of their basic needs (food, fodder, fuel, fiber and timber). Natural hazards like landslides in the hills, flooding in the foothills and Terai lowlands, and drought in the most of the areas of the country have been contributing to land degradation leading to poor socio-economic conditions and deterioration of natural ecosystems. Anthropogenic causes such as deforestation, overgrazing, and unscientific farming on steep slopes have resulted in loss of flora and fauna, and have caused soil erosion, landslides in the hills, and flooding in the plain areas as well. Slope Agriculture Land Technology (SALT) is one of the practices identified for promotion. Slope land management by plantation of fodder trees and appropriate crops such as citrus, tea and coffee on terrace to control erosion should be promoted in the mid-hills. Another option prioritized to stabilize the slopes is the hedge row planting. The alleys not occupied by permanent crops should be planted alternately to cereals such as corn, upland rice, cotton, fruits, vegetables, and legumes, etc. This cycle of cropping provides the farmers with several harvests throughout the year. The intervention would identify best suitable model for the mid-hill region.

Temperature records of the last 30 years indicate an increasing trend, and the warming seems to be consistent and continuous after the mid-1970s. The average warming in annual temperature between 1977 and 1994 was $0.06^{\circ} \mathrm{C} /$ year. Warming is more pronounced in high and mid-hill regions of Nepal. Warming in the winter is more pronounced compared to other seasons. Viable practices are tunnel/plastic house farming and off season vegetable cultivation and community centered small scale fruit (apple, apricot, walnut, mandarin), vegetable, potato seed storage, etc. Hence, priority should be given for the development of localized tunnel farming technology by using new ways and techniques that are being practiced along northsouth road accessible areas in the mid-hills from east to west of the country. Localized tunnel cultivation systems are sustainable and cause low environmental pollution to 
agriculture systems, in addition to reducing the high/low temperature risks that make income generation from off season production of vegetables; viz., tomato, cole crops (crops belonging to cruciferous family), etc.

Of the three climatic zones in Nepal, the Southwest zone is the Terai lowland plains, which are the northern extension of the Gangetic Plains. These areas have alluvial soils and an elevation of 100-300 meters above mean sea level (amsl).

The middle zone comprises the less densely populated hills, which are cut by a series of valleys. The altitude ranges from 250-4,00om, and the zone is characterized by steep valleys that are often terraced for extensive agriculture. The topography of the hill zone results in different microclimates that can be suited to specific crops.

To the north is the mountain zone which extends to over 8,ooom elevation.

From the climatic point of view, in the plains or Terai lowlands are hot and humid or subtropical to tropical climate, while in the hills have both a subtropical climate in the foothills and temperate climate on the top of the hills. Based on climatic suitability, rice, wheat, legumes and oilseeds are the major commodities of the Terai. Rice, maize, wheat, pulses and oilseeds are major commodities in the hills. And potato, barley, wheat, buckwheat, amaranth, and different millets are the commodities suitable for the mountains. These differences favor different cropping patterns; however, there are local scales dry and wet spells that affect these crops, hence intercropping systems are needed to stabilize productivity.

Seed is the important input for increasing productivity and meeting food security. There is less than $8 \%$ formal seed replacement of improved varieties of important food crops and around $92 \%$ of seed replacement comes from farmers to farmers or informal sources of seeds produced locally. Quality seed alone can increase crop yields up to $10-25 \%$. Seed production groups for important food crops (rice, maize, wheat, barley, millet) have shown encouraging results in many parts of the country. Improved seed produced by users' groups in a community based concept has helped increased crop production. This practice is one of the coping measures to mitigate climate change effect by availing quality seed to local communities.

Resource conservation is based on the principle of less soil disturbance, crop rotation, and residue incorporation. Along with other resource-conserving farming practices, conservation agriculture can improve rural incomes and livelihoods by reducing production costs, managing agroecosystem productivity, encouraging diversity for more sustainably, and minimizing unfavorable environmental impacts, especially in small and medium-scale farms. Rice and wheat yields in warm environments can be raised significantly by modifying agronomic practices of timely planting, incorporating residues and following appropriate crop rotations as proved beneficial in resource conservation techniques. Clearly, rice, wheat and maize yields in lower latitudes may decrease due to global warming, and may be further affected by water scarcity or drought. One approach to dealing with these heat-related constraints is to improve rice, wheat and maize germplasm to provide higher tolerance to stresses associated with these environments. Hence, new varieties screened by Nepal Agriculture Research Council (NARC) should be demonstrated to farmers focusing on enhancing the crop yield potential and to maintain yield under higher temperatures. In this way, they will assist in building cropping systems resilience to the global warming and natural hazards that could jeopardize the livelihood of resource-poor farmers who depend on the harvest of these crops.

\section{Nepal's Efforts to Address Climate Change}

A cabinet meeting of the Council of Minister of the Government of Nepal (GON) was held at the base of Everest in December 2009. The meeting came ahead of the United Nations Climate Summit in Copenhagen (known as Cop15), which began on 15th December 2009. A 10-point 'Everest Declaration' of the cabinet includes developing communities' capacity to cope up with climate change and working together with other countries to mitigate the impact of global warming (Shrestha 2009). The declaration also supported developed countries' plans to contribute $1.5 \%$ of GDP to a climate fund and bring down greenhouse gases to pre-industrialization levels.

Nepal is an agricultural based country where more than $65 \%$ population depends on agriculture and more than $32 \%$ of GDP comes from the agriculture as well. If the Himalayan peaks are devoid of snow what would be the fate of rivers flowing from those mighty water towers, the Himalayas? The Himalayas are responsible to supply water to the perennial rivers flowing in the Indo-Gangetic, the Mekong, and Tibetan plateaus. Ultimately, Europe and the entire Asia-Pacific region would be affected immediately and in the long run the impact would be for the entire earths' civilization and the climate as a whole. Hence, there is no question of victimizing from the impact of climate change for a single country like Nepal whose contribution on global climate is negligible (around 0.02\%); i.e., miniscule compared to developed and industrialized countries (Paudel 2010). In Nepal, negative impacts of climate change are observed for food crops by infection of diseases and pests such as club root of crucifiers, blight of Solaneceous, rust of wheat, blast of rice and leaf spot of maize and red ants which have become menace leading to decreasing crop productivity. Until and unless such issues are tackled timely, there are less likely chances of coping climate change with respect to food security and poverty reduction to meet the MDGs set by the UN for 2015 for developing countries (Paudel 2010).

\section{Rice}

Rice varieties such as Lalka Basmati, Ghaiya 1 \& 2, B-6144, Sukhha Dhan-1, 2, and 3, and IR-44535-5 have been developed for cultivation in drought stress condition (NATWGs 2010). These can withstand drought and can yield even in some fluctuation of moisture which should not be limiting for rice under general condition. These varieties can be cultivated as direct seeding when the rainfall is unpredicted and there are very slim chances of cultivating transplanted rice as a result of change in rainfall patterns.

On the other hand, varieties such as Sworna, IR-64, and Sanwa Mansuli are introgressed containing sub-1 gene which is submergence tolerant. It has been reported that up to 17 days of complete submergence, variety 
Sworna Sub-1 can withstand and give yield as that of other varieties which are cultivated under normal irrigation condition. Due to uncertainty of heavy flooding, there are areas which are completely inundated up to two weeks; these varieties are recommended as adoption practices in flooding conditions of low lying area of rice cultivation. For high hill and temperate conditions (2,500m and above in elevation) rice varieties Chandannath-1 \& 3 have been developed and popularized especially in Jumla and Karnali regions (Paudel 2011) where there is acute shortage of food and where, as of now, around 3.9 million people in the area are suffering from hunger and malnutrition (Paudel 2010).

Similarly, rice varieties Machhapuchhere-3 and Chhomrong Local have been popularized in upper high hills of more than 2000m (Karki, Koirala and BK 2010).

\section{Maize}

Maize varieties of Manakamana-5 (white), Manakamana-6 (yellow), and Deuti (white) have been recommended for the mid-hills. These varieties are tolerant to lodging stay green after maturity as important fodder for animals, and in farmers' field condition they give grain yield up to $5 \mathrm{t} / \mathrm{ha}$. These are equally fit for maize plus finger millet inter-cropping systems in the mid-hills where this is very prominent cropping pattern.

\section{Wheat}

A wheat variety of Aditya (BL-3264) has been recommended for high temperature and hot wind tolerant, leaf rust and yellow rust resistance. Similarly, recently released variety NL-971 is resistant to leaf rust, moderately resistant to yellow rust and Helminthosporium leaf blight, and tolerant to high temperature. Likewise, variety WK1204, Pasang Lahmu, and Gautam which are tolerant to yellow rust that caused serious losses to wheat in the midhills. These are gaining popularity in yellow rust prone areas of the mid-hills. These varieties of wheat could give grain yield of 2.0 to $3.5 \mathrm{t} /$ ha even under extreme climatic condition of drought, flood, low temperature, and insect pest incidences brought about primarily by the impact of climate change.

\section{Hybrid tomato}

Tomato is an important commodity in the Nepalese food chain. Tomatoes have been suffering from the infection of blight. To address this menace, NARC has developed hybrid tomato cultivars Srijana and Bishesh for general cultivation and off-season (plastic tunnel) cultivation. These are tolerant to blight, high yielder (20 t/ ha), and suitable for off season production (June-October) in the rainy season. These varieties are even popular in India and have been exported to bordering Indian states, as well.

\section{Miscellaneous}

Aside from releasing different varieties of crop, NARC has recommended technologies to address vagaries of climate change; these include resource conservation technologies (zero tillage, bed planting, permanent bed planting, strip tillage, minimum tillage, surface seeding, crop residue management, etc.). There are composite technologies to address the effects of climate change on agriculture; these include gray leaf spot disease management of maize by growing resistant varieties like Ganesh-1, Manakamana-1\&2, and Deuti. The crop husbandry technologies to mitigate adverse effect of climate change are early planting and wide spacing, balanced use of chemical fertilizers and integrated nutrient management, integrated pest management, and selective application of pesticides (Carbendazim/Benomyl or DM$45 / \mathrm{Saf}$ ) to get rid of grey leaf spot of maize.

Nepal is blessed with diverse climate conditions ranging from $60 \mathrm{~m}$ to $8,848 \mathrm{~m}$, the top of the world. Due to climate change many indigenous breeds and varieties of crops are in the verge of extinction. These flora and fauna of plants and animals have been a boon for the resource poor populace of Nepal. They include many indigenous crop species of aromatic rice: Basmati, Thapa Chini, Kalanamak, Jhinuwa, Kanak Jira, Chananchura, Tunde Masino, Anandi (red and white), many local varieties of rice (Ghaiya, Jund, Marshii), wheat, maize (Sathiya, Murali, Dhinde, Sete, Panheli), finger millet (Okhle, Dalle, Paundure, Jhapre, Mutthe), many grain legumes, vegetable legumes, and other minor crops (foxtail millet, sorghum, buckwheat, naked barley, panicum millet, amaranthus, etc.). Likewise, for animals including buffalo (Parkote, Lime), cattle (Yak and Lulu of high hills), Achhamigai (smallest cow recorded in the world), goat (Chyangra for Pasmina wool), Bhyanjlung of sheep (carpet wool production), Khari goat, Bampudke Sungur (native pig), Sakhini Kukhura (native fowl), and many other unrecorded species of crops and animals are endangered. There is a need to conserve such very important genetic materials which are becoming endangered due to the effect of climate change.

\section{Conclusion}

It has been experienced that effect of climate change in general and agriculture in particular has been observed in Nepal. Changes in agriculture in varied agro-ecology of mountain, hill and Terai are observed with decrease in agriculture productivity due to the untimely onset of monsoon including erratic rain, flood, land slide and droughts. Consequences of all such natural phenomena has resulted food and nutritional shortage in Nepal. Role of Nepal in global climate change is minimal compared to its negative effect on agriculture which is the main stay of Nepalese people. Adaptation and mitigation are the available tools to address effect of climate change. There is very little to do with mitigation as Nepal does not emit significant quantity of greenhouse gases and the only way is the adaptation to cope up with vagaries of climate change. Development of crop varieties and animal breeds to suit into changed environment are the viable adaptation strategies which could best address climate change scenario in Nepal. In this regard, NARC has developed and maintained crop varieties and animal breeds to address climate change and such technologies have been popularized in the agro-ecological niches wherever feasible. This has helped, to some extent, sustain food security, and enhance livelihood in Nepal as well. 
Mina Nath Paudel, PhD, studied Agronomy, Soil Science, and Agro-Meteorology at the University of the Philippines, Los Baños (UPLB). He has published more than four dozen research articles in national and international referred journals/proceedings/workshops. At present, he is president of the Agronomy Society of Nepal (ASoN), Editor-in-Chief of the Agronomy Journal of Nepal (Agron JN), life member of the ASoN, Society of the Agriculture Scientist (SAS)-Nepal, member of the Agriculture Federation Nepal (AFN), and Division Chief/Senior Scientist at the Outreach Research Division, Khumaltar, Lalitpur District under the Nepal Agricultural Research Council (NARC).

Corresponding email: mnpaudel@yahoo.com

\section{References}

CEU (Central European University), 1999, 'Definition of climate change', as cited in M.N. Paudel, 2010, 'Effect of climate change on food production and its implication in Nepal', Agronomy Journal of Nepal, 1:40-49.

Ellina, L. and D.S. Tirpak, 2006, Adaptation to Climate Change: Key Terms, Paris: Organization for Economic Co-Operation and Development, International Energy Agency.

Faisal, I. and S. Parveen, 2004, 'Food security in the face of climate change, population growth, and resource constraints: implications for Bangladesh', Environ Manage 34:487-498.

FAO, 2009, 'Climate change impacts on agriculture and food security and disaster risk management as entry point for climate change adaptation'; URL: www.fao. org/docs/up/easypol/778/climate-change_impacts_ on_agric_food_security_slides_077EN.pdf.

FAO, 2008, 'Climate change adaptation and mitigation: challenge and opportunity for food security'; URL: www.fao.org/docrep/fao/meeting/o13/k2545e.pdf.

Gifford, R.M., 1987, 'Exploiting the fertilizing effect of high levels of atmospheric carbon dioxide', Proceedings of the International Workshop on Climate Variability and Food Security in Developing Countries, February 6-9 1987, New Delhi.

Harman, J., M. Gawith and M. Colley, 2005, 'Progress on assessing climate impact through the UK climate impact program', Weather 60(9):258-262; URL: www. onlinelibrary.wiley.com/doi/10.1256/wea.105.05/pdf.

Hay, J. and N. Mimura, 2006, 'Supporting climate change vulnerability and adaptation assessments in the Asia-Pacific region: An example of sustainability science', Sustainability Science 1:23-35.

IPCC, 2001, Climate Change 2001, Impacts, Adaptation and Vulnerability, London: Cambridge University Press, for the Intergovernmental Panel on Climate Change.

Karki, T.B., K.B. Koirala, and S.B. BK, 2010, 'Participatory variety selection of cold tolerant rice in the western hills of Nepal', Agronomy Journal of Nepal 1:74-79.
Malla, G., 2008, 'Climate change and its impact on Nepalese agriculture', Journal of Agriculture and Environment 9:62-71.

NARC, 1987-1998, Annual Reports, Kathmandu: Nepal Agricultural Research Council.

NATWGs, 2010, in T.P. Barakoti and M.N. Paudel (eds.), Proceedings of the Seventh National Agricultural Technical Working Group Workshop, July 9, 2010, Kathmandu, Nepal Agricultural Research Council (NARC).

Paudel, M.N., 2010, 'Effect of climate change on food production and its implication in Nepal', Agronomy Journal of Nepal, 1:40-49.

Paudel, M.N., 2011, 'Rice cultivation in the highest elevation in the world', Agronomy Journal of Nepal 2:31-41.

Regmi, H.R., 2007, 'Effect of unusual weather on cereal crops production and household food security', Journal of Agriculture and Environment 8:20-29.

Rosenberg, N.J., 1987, 'Drought and climate change: For better or worse?', pp.317-347 in D.A.Willhite and W.E. Easterling, with D.A. Wood (eds.), Planning for Drought: Toward a Reduction of Societal Vulnerability, Boulder, Colorado: Westview Press.

Sherpa, A., 2010, 'Campaign ambassador speaks Mr. Apa Sherpa', Climate for Life: A Call from the Himalayas (World Wildlife Fund). URL: http://climate4life.org/ the-campaign/campaign-ambassadors/apa-sherpa. html.

Shrestha, M., 2009, 'Everest hosts Nepal cabinet meeting', CNN (Cable News Network, USA). URL: http:// articles.cnn.com/2009-12-04/world/everest.cabinet. meeting 1 .

Sinha, S.K., N.H. Rao, and M.S. Swaminathan, 1988, 'Food security in the changing global climate', Proceedings of the conference on Changing Atmosphere: Implications for Global Security, 27-30 June 1988, in Toronto, Canada.

Theodore, H.J. (ed.), 2001, Glossary: Climate Change 2000: The Scientific Basis, Contribution of Working Group I to the Third Assessment Report of the Intergovernmental Panel on Climate Change (IPCC), Cambridge, UK: IPCC. URL: www.ipcc.ch/ publications_and_data/publications_and_data_ reports.shtml.

UNFCCC, 1992, United National Framework Convention on Climate Change. URL: http://unfccc.int/resource/ docs/convkp/conveng.pdf.

US EPA, n.d., Glossary of Climate Change Terms, Washington DC: U.S. Environmental Protection Agency; URL: www.epa.gov/climatechange/glossary. html\#Climate.

World Bank, 2008, Climate Change and Development, Washington DC: The World Bank. URL: siteresources. worldbank.org/IDA/Resources/IDA-Climate_Change. pdf. 